\title{
Stock Price and Volume Effects Associated with changes in the Composition of the FTSE Bursa Malaysian KLCI
}

\author{
Alcino Azevedo ${ }^{1,2 *}$, Mohamad Karim*, Andros Gregoriou* and Mark Rhodes \\ *Hull University Business School
}

\begin{abstract}
We examine the stock price and volume effects associated with changes in the composition of the FTSE Bursa Malaysia Kuala Lumpur Composite Index (KLCI), over the time period of 2005 to 2012. We find evidence to support the price pressure hypothesis for both additions to and deletions from the KLCI. This is because significant stock price and trading volume effects in the pre index revision period are entirely reversed after the announcement of the news. Our empirical findings can be explained by the market microstructure literature. Significant changes in liquidity causes trading volume and stock prices to reverse back to their original level before the index revisions took place.
\end{abstract}

JEL Classification: G12, G14.

Keywords: Addition, Deletion, Index Revision, Price Effect, Liquidity Effect, Volume Effect.

\footnotetext{
${ }^{1}$ Corresponding author: a.azevedo@ hull.ac.uk, Tel.: +44(0)1482463107, Fax: +44(0)1482463484.

${ }^{2}$ Acknowledgments: we thank Aydin Ozkan, Yilmaz Guney, Claúdia Custódio and Benoît Detollenaere, and the participants at the Doctoral Conference held at the Hull University Business School, 2011, the Applied Financial Economics Conference, Samos, 2012, and the Portuguese Finance Network Conference, Aveiro 2012, for comments on earlier versions. Mohamad Karim gratefully acknowledges financial support from the University of Hull.
} 


\section{Introduction}

It is well established in the academic literature that changes in the composition of the stock indices are usually implemented shortly after the "announcement date" (AD). These events along with the time between the AD of changes in stock indices and the effective "change date" (CD), have provided rich information for understanding how stock prices are affected by stock index changes (see, for instance, Harris and Gurel (1986), Lynch and Mendenhall (1997), Hedge and McDermott (2003), Vespro (2006) and Gregoriou (2011)).

A market in which prices always "fully reflect" available information is called "efficient" (see Fama (1970)). The "efficient market hypothesis" (EMH) states that security prices fully reflect all publically available information and rational investors should not react to informationless events. Several hypotheses have been tested, particularly for the US and the European markets, to examine the stock prices reaction to changes in the composition of stock indices (see among others, Shleifer (1986), Harris and Gurel (1986), Dhillon and Johnson (1991), Bechmann (2004) and Vespro (2006)). Bounces and reversals are inconsistent with the EMH, where it is also implicitly assumed that securities are near perfect substitutes for each other, and so the excess demand for a single security will be very elastic, and the sale or purchase of a large number of shares have no effect on share prices.

The "imperfect substitutes hypothesis" (ISH) assumes, however, that securities are not close substitutes for each other and, therefore, the long-term demand is less than perfectly elastic, i.e. the equilibrium prices change when demand curves shift to eliminate excess demand and price reversals are not expected because the new price reflects a new equilibrium distribution of securities holders (see, for instance, Scholes (1972), Shleifer (1986), Hanaeda and Serita (2003), Bechmann (2004), Vespro (2006), and Bildik and Gülay (2008)). The "price-pressure hypothesis" (PPH) assumes that the long-term demand is perfectly elastic at full-information price. It holds if stock prices reverse to their ex-ante level after the index change, and recognizes that immediate information about non-information-motivated demand shifts may be costly and, consequently, the short-term demand curve may be less than perfectly elastic. Harris and Gurel (1986), Woolridge and Ghosh (1986), Dhillon and Johnson (1991), Liu (2001), Madhavan (2003), Chen et al. (2004), Vespro (2006, and Yun and Kim (2010), among others, support the PPH. The "information hypothesis" (IH) states that, in efficient markets the positive (negative) information about a stock should increase (decrease) immediately its price and the information effect should be permanent. Hence, stock prices should correctly reflect the information content of the indices additions and deletions and reach a new equilibrium level upon the AD. Jain (1987), Lynch and Mendenhall (1997), Denis et al. (2003) and Liu (2011) provide results for the IH. The "information cost and liquidity hypothesis" (ICLH) asserts that adding a stock to an 
index leads to a higher market scrutiny and information available, and that this raises the attractiveness and the liquidity of the stock and has a positive effect on the price. Stoll (1978) and Beneish and Gardner (1995), Heflin and Shaw (2000), Hedge and McDermott (2003), Gregoriou (2011), among others, support the ICLH.

The earliest studies on the association between stock prices bevaviour and changes in stock indices were based on the U.S. market. Shleifer (1986) and Harris and Gurel (1986), for roughly the same time period (the former article for 1966-1983 and the latter for 1973-1983) provide evidence of a strong positive stock price reaction to the announcement of additions to the S\&P 500 index. Shleifer (1986) findings support the ISH and Harris and Gurel (1986) results support the PPH. Dhillon and Johnson (1991) questioned, however, the Shleifer (1986) and Harris and Gurel (1986) implicit assumption that stock additions to the S\&P 500 index, per se, is informationless, and re-examined, for the period between 1978 and 1988, the ISH and PPH, showing that the stock prices do not reverse to their previous return levels even 60 days after the AD. Also for the S\&P 500, using a sample from March 1990 to April 1995, Lynch and Mendenhall (1997) show that there is positive abnormal return on the AD, which reverses only partially after the $\mathrm{CD}$, providing support for the idea that there is a temporary component to the stock price increase. Elliott and Warr (2003), using additions of NYSE (and Nasdaq listed) firms to the S\&P 500 index examine the effect of non-informative related demand shocks and show that NYSE stocks suffer less pronounced price effects than do the Nasdaq stocks on the $\mathrm{CD}$ and the price effect is reversed immediately, while for the Nasdaq stocks the price reverses only partially and over several days. A good survey about the hypotheses for the increase in stock prices associated with additions to the S\&P 500 index is provided by Elliott et al. (2006).

There is also a rich literature examining the association between index changes and stock prices behaviour for European stock markets. For the Danish blue-chip KFX Index, Bechmann (2004) reports that there is no evidence of a stock price effect at the AD of the stock index change. His results support best the ISH or ICLH. For the French CAC 40 index, the SBF120 and the London FTSE 100 indices, Vespro (2006) provides evidence supporting the PPH associated with index fund rebalacing, but weak or no evidence for the ISH and the liquidity hypothesis. Also for the CAC 40 index, Gregoriou (2011) examines the liquidity effects folllowing the index revision for the period between 1997 and 2001. His results suggest that there is a sustained increase (decrease) in liquidity of the added (deleted) stocks and that the improvement (reduction) in the liquidity of the stocks is due to a decrease (increase) in the direct cost of trading as oposed to a reduction (enhancement) in the asymmetric information cost of transacting. For the FTSE 100 stock index, Gregoriou and Nguyen (2010) studies the association between liquidity and investment opportunities, for a context where firms are 
experiencing a negative exogenous liquidity shock captured by deletion from the index. Somewhat surprisingly, his findings contradict the extensively reported positive relationship between liquidity and investment opportunities for the US equity market. Table 1 provides a summary of the theories mentioned above along with the relevant academic literature associated with each of them.

\section{[INSERT TABLE 1 HERE]}

Empirical studies on the association between index changes and stock price behaviour for the Asian markets are still limited, and mainly devoted to the Japanese equity market. Liu (2000) considers the effect of changes in the Nikkei 500 on the stock prices and the trading volumes, and finds evidence supporting the downward sloping demand curves hypothesis. Liu (2011) explores a new explanation (volatility-explanation) for the permanent price effect of index additions for the Nikkei 225, and shows that the stock's volatility plays a significant role on the permanent price increase. There is one study on the Korean stock market (Yun and Kim, 2010), which provides evidence of permanent price effects and partial return reversal.

Our study is the first attempt to provide a comprehensive analysis of index change effects on the Kuala Lumpur Composite Index (KLCI). The Malaysian stock market is one of the leading Asian emerging markets with significant growth in the last decade ${ }^{3}$, and the KLCI is currently internationally recognized as one of the best references for the Asia-Pacific equity markets, used by most analysts to comment on the economic prospects for the Malaysian and other important Asian economies ${ }^{4}$. It was set in 1986 with 70 constituents, reaching 100 constituents in 1995. In July 6, 2009, the Bursa Malaysia (BM) and the FTSE group announced that it would be split into two new indices, one with 30 constituents, named FTSE BM KLCI 30 (KLCI) ${ }^{5}$, and another with 70 constituents, named FTSE BM MID 70 (KLCI 70).

The above changes, along with the fact that candidates to be added to or deleted from the KLCI, and the dates where the index change will take place, are known in advance (different, for

\footnotetext{
${ }^{3}$ See http://www.ftse.co.uk/Indices/FTSE_Bursa_Malaysia_Index_Series/index.jsp.

${ }^{4}$ The FTSE BM Index is composed of 7 benchmark indices (FTSE BM KLCI, Mid 70, 100 index, Emas, Small Cap, Fledging and ACE) and 6 tradable indices (FTSE BM KLCI, Mid 70, 100 index, Hijrah Shariah Index, Asian Palm Oil Plantation Index (traded in MYR and USD), Asian Palm Oil Plantation Index, traded in Chicago Mercantile Exchange).

${ }^{5}$ The KLCI is a price weighted average of 30 actively traded stocks on the BM, previously known as Kuala Lumpur Stock Exchange, went public in 2004. Until August 2009 there were three markets: the Main Board (high capital), the Second Board (small \& medium capital) and the MESDAQ (high growth and technology based constituents). After August 2009, the Main Board merged with Second Board, leading to the now called Main market, and the MESDAQ was upgraded and renamed as the ACE market. Large and medium size firms are listed on the BM Securities Main market and high growth and technology firms on the ACE market.
} 
instance, from the rules used to implementing changes in the S\&P 500 where there is a list of candidates to be included but the identity of the firms is kept secret until the announcement of the change) provide an unusual opportunity to examine the effect of changes in the index composition on the stock prices ${ }^{6}$. These features allow us to extend the Lynch and Mendenhall (1997) test, by isolating the PPH from the ISH and testing the downward sloping demand curves hypothesis. Vespro (2006) performed this test for European stock indices. We include free float in our analyses to examine the association between free float, "abnormal" volume and changes in the KLCI.

The remaining sections of the paper are organized as follows. In section 2, we describe the data sample and the methodology. In section 3, we provide our results and analyses. In section 4, we conclude and make suggestions for further work.

\section{Data and Methodology}

\subsection{Data}

Our dataset is composed of daily stock prices, adjusted for dividends and stock splits, daily trading volumes for the stocks and indices, and FF data, for the period between 2005 and 2012. The FF share percentage is the amount of shares, given as a percentage of the total number of shares outstanding, available to ordinary investors. The last index CD of the sample is August 1 , 2012. But the dataset comprises daily stock prices and daily stock and indices trading volumes until September 15, 2012. The KLCI 100 was split into two new indices, the KLCI and the KLCI 70 on July 6, 2009. As proxy for the market portfolio we use the KLCI 100, for the period before July 6, 2009, and the KLCI 70 for the period after July 6, 2009. The data about the stock prices and indices values, and respective trading volumes, and the FF data types ${ }^{7}$ was collected

\footnotetext{
${ }^{6}$ Changes in the composition of the FTSE BM indices obey to pre-specified criteria. More specifically, all classes of ordinary shares in issue are eligible for inclusion in the FTSE BM KLCI subject to conforming to all other rules of eligibility, free float and liquidity. Securities must be sufficiently liquid to be traded and accurate and reliable prices must exist to determining the market value of a firm. Inclusion in the stock index is also based on market capitalisation according to the FTSE Ground Rules.

${ }^{7}$ Our free float data types includes: "Government Held Shares" (NOSHGV), i.e. the percentage of strategic holdings (of $5 \%$ or more) held by the government or by government related institution; "Employee Held Share" (NOSHEM), i.e. the percentage of strategic holdings (of 5\% or more) held by employees, or those with a substantial position in the company's shares that leads to a relevant voting power at annual general meeting (typically family members); "Cross Holdings Shares" (NOSHCO), i.e. the percentage of strategic holdings (of 5\% or more) held by one company in another; "Pension Fund Held Shares" (NOSHPF), i.e. the percentage of strategic holdings (of 5\% or more) held by endowment funds or pension funds; "Investment Company Share" (NOSHIC), i.e. the percentage of strategic holdings (of 5\% or more) held by investment banks or institution (excluding hedge funds) seeking a long term return; "Other Holdings Shares" (NOSHOF), i.e. the percentage of strategic holdings (of 5\% or more) outside one of the above categories; NOSHFF is the percentage of total shares in issue available to
} 
from the Datastream. The information regarding the $\mathrm{AD}$ and the $\mathrm{CD}$ for the additions to and deletions from the index was collected from the Secretary of the FTSE BM Advisory Committee. Our initial sample comprises a total of 34 additions to and deletions from the index. After filtering for the M\&A, spin-offs and the unavailability of data it dropped however to 28 changes, with 15 additions and 13 deletions. Table 2 below provides further details about the data sample.

\section{[INSERT TABLE 2 HERE]}

\subsection{Methodology}

\subsubsection{Return and Trading Volume}

The Bursa Malaysia announces changes in the KLCI in trading days, therefore, in the methodology below the stock price and the trading volume of the $\mathrm{AD}$ and $\mathrm{CD}$ are the closing stock prices and the trading volumes of the day. The abnormal return (AR) of stock $i$ on the time-period $t\left(A R_{i, t}\right)$ is the difference between the stock $i$ 's return and the market's return for the time-period $t$, according to equation (1):

$$
A R_{i, t}=R_{i, t}-R_{m, t}
$$

where, $R_{i, t}$ and $R_{m, t}$ are the stock $i$ 's return and the market's return over the time-period $t$, respectively.

As proxy for the market's return, we use the KLCI 100's return for the period before July 6 , 2009 (i.e. before the split of the KLCI 100), and the KLCI 70 for the period after July 6, 2009 (i.e. for after the split of the KLCI 100). We determine the "mean cumulative abnormal return" (MCAR) for several event-windows (and dates). To measure the AR over an event-window $\left(t_{1}-t_{2}\right)$, we compute the "mean cumulative abnormal returns", $M C A R_{\left(t_{1}-t_{2}\right)}$ - defined as the summation of the "cumulative abnormal return", $C A R_{\left(t_{1}-t_{2}\right)}$, of each constituent divided by the number $(N)$ of constituents in the (additions/deletions) sample.

To take into account for the fact that the return variance may increase due to the changes in the index we use the standardized cross-sectional test of Boehmer et al. (1991), which standardizes the AR of each stock $i$ on the event day $E$ by the standard deviation of the AR of the estimation

ordinary investors; and "Total Strategic Share Holdings" (NOSHST) represents the percentage of company's share outstanding (of 5\% or more) that is not available to ordinary investors, computed as the summation of the NOSHGV, NOSHEM, NOSHCO, NOSHPF, NOSHIC and NOSHOF. 
period $e$ - defined as the period between 60 days before the AD (AD-60) and 40 days before the $\mathrm{AD}(\mathrm{AD}-40)$.

$$
S A R_{i, E}=\frac{A R_{i, E}}{\sigma_{i} \sqrt{1+\frac{1}{T_{i}}+\frac{\left(R_{m, E}-\bar{R}_{m, e}\right)^{2}}{\sum_{t=1}^{T}\left(R_{m, t}-\bar{R}_{m, e}\right)}}}
$$

where, $S A R_{i, E}$ is the standardized abnormal return of stock $i$ on the event date $E$; $A R_{i, E}$ is the abnormal return of stock $i$ on the event date $E ; \sigma_{i}$ is the standard deviation of stock $i$ over the estimation period $e ; T_{i}$ is the number of days used as the estimation period, $e$, for the stock $i$; $R_{m, E}$ is the market return on the event-window/date $E ; \bar{R}_{m, e}$ is the average market return on the estimation period $e$; and $\bar{R}_{m, t}$ is the market return on day $t$.

For calculation of the $t$-statistic test we use equation (3):

$$
t=\frac{\frac{1}{N} \sum_{i=1}^{n} S A R_{i, E}}{\sqrt{\frac{\sigma_{S A R_{i, E}}^{2}}{N}}}
$$

where, $N$ is the number of firms in the sample and $\sigma_{S A R_{i, E}}^{2}$ is the variance of $S A R_{i, E}$.

To test for abnormal trading volume we use the Harris and Gurel (1986) methodology, through equation (4).

$$
V R_{i, E}=\frac{V_{i, E} / V_{m, e}}{V_{m, E} / V_{i, e}}
$$

where, $V_{i, E}$ and $V_{m, E}$ are the trading volumes of stock $i$ and the market on the event date $E$, respectively, and $V_{m, e}$ and $V_{i, e}$ are the average trading volumes of the market and the stock $i$ for the estimation period $e$, respectively. The volume ratio, $V R_{i, E}$, is a standardized measure of the trading volume of stock $i$ in the time period $t$, adjusted for the market variation. Its expected value is 1 if there is no change in volume during the event date $E$ relative to the estimation period $e$. We average the volume ratios across the number of firms, $N$.

We use three event-windows in our analysis: the "pre-announcement period", period between 15 days before the $\mathrm{AD}$ and the $\mathrm{AD}$ ( $\mathrm{AD}-15$ to $\mathrm{AD}$ ); the "announcement period", period between the $\mathrm{AD}$ and the $\mathrm{CD}$ ( $\mathrm{AD}$ to $\mathrm{CD}$ ), and the "post-change date period", period between the $\mathrm{CD}$ and 15 days after the change date $(\mathrm{CD}$ to $\mathrm{CD}+15)$. 


\subsubsection{Market Liquidity}

The analysis of the aggregate trading volume alone does not provide sufficient information to infer whether the changes in the trading volumes are due to liquidity changes or informationmotivated. We test the liquidity changes using Hedge and McDermott (2003) methodology, a pooled time series cross-sectional multivariate analysis of quoted spread and depth. This allows us to examine whether the market liquidity of stocks increases (decreases) following additions to (deletion from) the KLCI, controlling for the average daily trading volume, the average daily closing stock price and the daily volatility of the stock return, through the following log-linear specification where the regression coefficients provide estimates of the elasticity:

$$
\begin{aligned}
\log L i q_{i, t}= & B_{0}+\delta_{0} D \_K L C I_{t}+\beta_{1} \log V_{\mathrm{ol}} \mathrm{l}_{i, t}+\delta_{1} \log \operatorname{Vol}_{i, t} D \_K L C I_{t}+\beta_{2} \log \text { Price }_{i, t}+\ldots \\
& \ldots+\beta_{3} \log \operatorname{StdDev}_{i, t}+\varepsilon_{i}
\end{aligned}
$$

where, for the stock additions $i=(1,2, \ldots 15)$ and for the stock deletions $i=(1,2, \ldots 13)$, with $t=(1,2)$, where $t=1$ represents the period between CD- 45 and CD-15 (before the index change) and $t=2$ the period between $\mathrm{CD}+15$ and $\mathrm{CD}+45$ (after the index change); $\log L i q_{i, t}$ is the dependent variable, represented by either the "quoted spread" ( $\left.\operatorname{logSpread}_{i, t}\right)$ the "effective spread" $\left(\operatorname{logSpread}_{i, t}\right)$, or the Malaysian Ringgit (MYR) depth $\left(\operatorname{logDepth}_{i, t}\right)$. We use the "return to volume" ( RtoV) and the "return to the trading" ( RtoTR) ratios as proxies for the MYR depth ${ }^{8}$. As independent variables we use $\log$ Price $_{i, t}, \log V_{i, t}$ and $\log \operatorname{StdDev}_{i, t}$ which represent, respectively, the natural logarithm of the stock $i$ 's daily closing price, daily trading volume in shares and daily return volatility, for the time period $t ; D_{-} K L C I_{t}$ is a dummy variable which takes the value of " 1 " for the period after the index change and " 0 " otherwise. We are mainly concerned with the change in the dummy variable $\delta_{0}$, and the change in the slope of trading volume $\delta_{1}$ as a result of index revisions.

For the RtoV analysis, we use the Amihud (2002) methodology, through equation (6):

$$
R t o V_{i t}=\frac{1}{D_{i t}} \sum_{d=1}^{D_{i t}} \frac{\left|\mathrm{R}_{\mathrm{itd}}\right|}{\mathrm{V}_{\mathrm{itd}}}
$$

\footnotetext{
${ }^{8}$ The variable $\operatorname{logSpread}_{i, t}$ represents the natural logarithm of the average daily quoted bid-ask spread and the effective bid-ask spreads. The transacted relative bid-ask spread is the transacted MYR bid-ask spread divided the transacted mid-point of the bid-ask. The relative effective bid-ask spread is twice the absolute value of the difference between the trade price and the prevailing quote mid bid-ask point, as a percentage of the quoted mid bid-ask point.
} 
where, $\mathrm{R}_{\mathrm{itd}}$ and $\mathrm{V}_{\mathrm{itd}}$ are, respectively, the return and the monetary volume of stock $i$ on day $d$ at month $t$, and $D_{i t}$ is the number of valid observation days in month $t$ for stock $i$.

For the RtoTR analysis, we follow Florackis et al. (2011), through equation (7) 9 :

$$
\operatorname{RtoTR}_{i t}=\frac{1}{D_{i t}} \sum_{d=1}^{D_{i t}} \frac{\left|\mathrm{R}_{\mathrm{itd}}\right|}{\mathrm{TR}_{\mathrm{itd}}}
$$

where, RtoTR $R_{i t}$ is the turnover ratio of stock $i$ on day $d$, and $D_{i t}$ and $\mathrm{R}_{\text {itd }}$ are defined as previously.

\subsubsection{Free Float}

In emerging markets government and family members (i.e. employees/directors) are (more) likely to intervene in the market as evidenced in recent literature (see, for instance, Bhanot and Kadapkkam (2006) and Tavakoli et al. (2012)). Hence, we include in our analysis the components of strategic holdings by class of shareholders, holding $5 \%$ or more of the total shares outstanding. We test the liquidity changes adjusting the Hedge and McDermott (2003) methodology described in the previous section. This allows us to examine whether the market liquidity of stocks increases (decreases) following additions to (deletion from) the KLCI, controlling for the following free float shareholdings: NOSHGV, NOSHEM, NOSHST and NOSHFF, and the daily volatility of the stock return, the average daily trading volume and the average daily closing stock price. We use the following log-linear specification, where the regression coefficients provide estimates of the elasticity:

$$
\begin{aligned}
\log \operatorname{Liq}_{i, t}= & B_{0}+B_{1} \log \operatorname{Vol}_{i, t}+D_{1} \log \operatorname{Vol}_{i, t} D_{-} K L C I+B_{2} \log \operatorname{Pr} i c e_{i, t}+B_{3} \log \operatorname{StdDev}_{i, t}+B_{4} N O S H G V_{i, t} D_{-} K L C I+\ldots \\
& \ldots+B_{5} \text { NOSHEM }_{i, t} D_{-} K L C I+B_{6} \operatorname{NOSHST}_{i, t} D_{-} K L C I+B_{7} \text { NOSHFF }_{i, t} D_{-} K L C I+\varepsilon_{i}
\end{aligned}
$$

\footnotetext{
${ }^{9}$ As argued by Florackis et al. (2011), the RtoV ratio cannot compare stocks with different market capitalization and therefore carries a significant size bias, i.e. small cap stocks are bound to exhibit lower trading volume (in monetary terms) than big cap stocks even when they exhibit the same turnover ratio. Under the Amihud (2002) RtoV ratio (equation 6), small cap stocks are automatically characterized as "illiquid" due to their size. Also, RtoV neglects investors' stock holding horizons, i.e. even though it attempts to proxy the cost of transacting, it is uninformative with respect to the frequency at which this cost is incurred.
} 
We use the following event windows in our free float paired two sample means for the free float percentages: $\mathrm{AD}-120, \mathrm{AD}-1$ to $\mathrm{CD}, \mathrm{CD}+120$; $\mathrm{AD}-30, \mathrm{AD}-1$ to $\mathrm{CD}, \mathrm{CD}+30$; $\mathrm{AD}-15, \mathrm{AD}-1$ to $\mathrm{CD}$, $\mathrm{CD}+15$; and $\mathrm{AD}-7, \mathrm{AD}-1$ to $\mathrm{CD}, \mathrm{CD}+7$.

\section{Results}

\subsection{Abnormal Return and Volume}

Table 2 reports our results for the MCAR and the VR for the event-windows for the stocks added to the KLCI. Figure 1 provides a graphic illustration of the MCAR.

\section{[INSERT FIGURE 1 HERE]}

Our results show that for the event-windows AD-15 to AD-1 and AD-15 to CD-1 the MCAR is equal to $3.6 \%$ and $3.1 \%$, respectively. They are both statistically significant at the 5\% level. For the remaining event-windows the MCAR fluctuates between negative and positive values but is not significant in all cases. The VR is highest at the CD (3.5) with statistical significance at the $1 \%$ level, and the second highest is at the event-window AD-15 to CD-1 (2.1), with statistical significance at the $10 \%$ level. There is also evidence of abnormal positive trading volume, for the other event-windows, however it is not statistically significant. These results support the $\mathrm{PPH}$, reflecting that stock prices gain due to additions (3.6\% for the event-window AD-15 to $\mathrm{AD}-1)$, and are almost completed reversed soon after the index announcement date $(-2.3 \%$ for the event-window $\mathrm{AD}$ to $\mathrm{CD}+15$ ).

[INSERT TABLE 3 HERE]

Table 4 reports our results for MCAR and the VR for the stock deleted from the KLCI. Figure 2 provides a graphic illustration of the MCAR.

\section{[INSERT FIGURE 2 HERE]}

For the stock deletions, there are more event-windows where the MCAR and the VR are statistically significant. More specifically, the MCAR for the event-windows AD-15 to CD-1 and $\mathrm{CD}$ to $\mathrm{CD}+15$ is equal to $-7.3 \%$ and $7.3 \%$ respectively, with statistical significance for both at the $1 \%$ level. For the event-windows $\mathrm{AD}-15$ to $\mathrm{AD}-1$ and $\mathrm{AD}$ to $\mathrm{CD}+15$ the MCAR is equal to, $-5.7 \%$ and $5.8 \%$ respectively, the former result is significant at the $5 \%$ level and the latter is significant at the $10 \%$ level. 
For the VR most of our results are statistically significant at least at the 5\% level. More specifically, for the event-windows AD-15 to AD-1, CD to CD+15, AD-15 to CD+15 and AD to $\mathrm{CD}+15, \mathrm{VR}$ is equal to $1.25,1.26,1.45$ and 1.41 , respectively, and in all cases statistically significant at the $1 \%$ level; for the $\mathrm{CD}$ and the event-window $\mathrm{AD}-15$ to $\mathrm{CD}-1 \mathrm{VR}$ is equal to 1.44 and 1.55 , respectively, and statistically significant at the $5 \%$ level.

These results provide empirical support the PPH, i.e. the stock prices losses due to delisting are almost completed reversed soon after the index change date. Our results for the deletions are statistically robust. The support for the PPH is reinforced by the fact that the largest negative MCAR occurs at the event-window AD-15 to CD-1 (-7.3\%), the largest positive MCAR occurs at the event-window $\mathrm{CD}$ to $\mathrm{CD}+15$ (5.8\%), and both of these results are statistically significant at the $1 \%$ level.

\section{[INSERT TABLE 4 HERE]}

\subsection{Liquidity}

Table 5 provides our results for the log-linear pooled cross-sectional multivariate regression analysis (equation 5), for stock additions. Under the log-linear specification of equation (5), the regression coefficients provide estimates of elasticities. We are mainly concerned with the change in the dummy variable, $\delta_{0}$, and the change in the slope of trading volume as a result of stock index revisions, $\delta_{1}$. We provide evidence of a positive and significant dummy variable $\left(\delta_{0}\right)$ and a negatively significant trading volume variable $\left(\delta_{1}\right)$ in the post index addition time period. The results are robust across all four measures of liquidity. This suggests that market makers increase bid-ask spreads as a result of the news, and that this reduction in liquidity causes trading volumes to decrease in the post index revision period. The increase in bid-ask spreads makes additions more costly to trade resulting in the price reversal that we observe in Table 5.

\section{[INSERT TABLE 5 HERE]}

Table 6 reports our findings for the log-linear pooled cross-sectional multivariate regression analysis (equation 5), for the stock deletions. The results are similar to the index additions displayed in Table 5. Once again there is significant evidence of a positive and significant dummy variable $\left(\delta_{0}\right)$ and a negatively significant trading volume variable $\left(\delta_{1}\right)$ in the post index deletion period. This suggests that market makers increase bid-ask spreads as a result of 
the news and that this reduction in liquidity causes trading volumes to decrease in the post index revision period. However, the major difference between the two sets of results is that for the deletions the effective bid-ask spread measure is insignificant for both $\delta_{0}$ and $\delta_{1}$. This suggests that liquidity for trades occurring within the bid and ask quotes remains unchanged as a result of companies being excluded from the index. This causes trading volume and stock prices to return to their level before the index revisions took place, thus providing more support for the price pressure hypothesis. This is a powerful empirical finding given that most trades occur within the bid-ask quotes.

\section{[INSERT TABLE 6 HERE]}

\subsection{Free Float percentage changes}

Table 7 reports the paired two sample means for the free float percentages of the NOSHGV, NOSHEM, NOSHGV+NOSHEM, NOSHST and NOSHFF, for the stocks added to the KLCI, for the event-windows, as well as the respective t-statistic. Our results show that the changes in the percentage of the government holding (NOSHGV), sum of the government holding and the family or employee holding (NOSHGV+NOSHEM) and shares in issue available to ordinary investors (NOSHFF) are is statistically significant at $1 \%$ level for the following event-windows: $\mathrm{AD}-120, \mathrm{AD}-1$ to $\mathrm{CD}, \mathrm{CD}+120, \mathrm{AD}-30, \mathrm{AD}-1$ to $\mathrm{CD}, \mathrm{CD}+30$ and $\mathrm{AD}-15, \mathrm{AD}-1$ to $\mathrm{CD}, \mathrm{CD}+15$; none of the free float percentage changes are statistically significant for the event-window AD-7, $\mathrm{AD}-1$ to $\mathrm{CD}, \mathrm{CD}+7$; the mean of the percentage of the family or employee holding (NOSHEM) changed slightly between AD-120,AD-1 and CD,CD+120 -statistically significant at 1\% leveland remained unchanged for the other event-widows.

\section{[INSERT TABLE 7 HERE]}

Table 8 provides our results for the log-linear pooled cross-sectional multivariate regression analysis (equation 8), for stock additions. Under the log-linear specification of equation (8), the regression coefficients provide estimates of elasticities. We are mainly concerned with the free float coefficients, $B_{4}$ and $B_{5}$, the strategic holding slope change coefficient, $B_{6}$, and the change in the slope of free float holding, $B_{7}$, as a result of index revisions $D_{1}$. The coefficient $B_{4}$ is negative but not statistically significant for the Log spread (quoted) and Log spread (effective), and positive but not statistically significant for the RtoV and RtoTR; the coefficient $B_{5}$ is 
positive but not statistically significant for all liquidity measures; the coefficients $B_{6}$ and $B_{7}$ are both positive and statistically significant for all the liquidity measures.

\section{[INSERT TABLE 8 HERE]}

Table 9 reports the paired two sample means for the free float percentages of the NOSHGV, NOSHEM, NOSHGV+NOSHEM, NOSHST, and NOSHFF for the stocks deletions from the KLCI, at the event-windows, as well as the respective t-statistic. Our results show that the changes in the government holding percentage (NOSHGV), sum of the government holding percentage and the family or employee holding (NOSHGV+NOSHEM), total strategic holding (NOSHST), and shares in issue available to ordinary investors (NOSHFF) are statistically significant at $1 \%$ level for all the event-windows; the changes in the family or employee holding (NOSHEM) are statistically significant at $1 \%$ level for AD-120,AD-1 to $\mathrm{CD}, \mathrm{CD}+120$ and AD-15,AD-1 to $\mathrm{CD}, \mathrm{CD}+15$, and not statistically significant for the other event-windows.

\section{[INSERT TABLE 9 HERE]}

Our results show that the percentage of shares in issue available to ordinary investors (NOSHFF) has a positive relationship with all liquidity measures. Market microstructure literature documents a negative relation between market capitalization and transaction costs (see, for instance, Stoll, 2000), where one explanation provided is based on the level of liquidity provision, i.e. the higher the market capitalization the more likely is that liquidity is provided. Based on this line of argument a positive association between NOSHFF and liquidity is expected. This relationship can be explained by assumption that all the other types of ownership are possibly informed traders. This links very well to market microstructure theory where Kim and Verrecchia (1994) state in their model that informed traders possess superior information over the market maker, because they are able to produce superior assessments of a firm's performance. This leaves the market maker at an informational disadvantage with respect to informed traders, resulting in them increasing the bid-ask spread.

Table 10 reports our results for the log-linear pooled cross-sectional multivariate regression (equation 8), for the stock deletions from the KLCI. Under the log-linear specification of equation (8) the regression coefficients provide estimates of elasticities. As for the additions to the KLCI, we are mainly concerned with the change in the government held shares (NOSHGV), 
employee held shares (NOSHEM), strategic holding (NOSHST) slope changes, $B_{6}$, and the change in the slope of free float holding (NOSHFF), $B_{7}$, as a result of stock index revisions, $D_{1}$.

The coefficients for the NOSHST and NOSHFF $\left(B_{6}\right.$ and $B_{7}$ ) are positive and statistically significant at $1 \%$ level for the log spread (quoted), RtoV and RtoTR variables. This suggests that government does provide liquidity using log spread liquidity measure and the rest are provided by public and other strategic shareholders. The coefficient for the employee or family member shareholding (NOSHEM) is not statistically significant, for all liquidity measures. The results suggest that when we use the quoted bid-ask spread the government appears to provide liquidity to the market. However, once we consider the bid-ask spread relative to share price changes and account for trades occurring within the bid-ask quotes, liquidity is provided by the public and strategic shareholders. Given that bid-ask spreads should consider the impact of the share price and quotes that occur within the ask and bid price, we conclude that liquidity is provided by the public and strategic shareholders.

\section{[INSERT TABLE 10 HERE]}

\section{Conclusions}

This paper provides empirical evidence of temporary price pressure effects in the KLCI revisions, particularly for the time period close to the $\mathrm{AD}$ and the $\mathrm{CD}$. Our findings support the PPH and are particularly robust for the stock deletions where stock prices reverse to preannouncement date levels at or near the $\mathrm{AD}$, with most of the abnormal returns significant either at $1 \%$ or $5 \%$ level. The analaysis of the MCAR pattern for the additions (Table 3) also supports the PPH although our results for this case are statistically less robust than those we found for the stock deletions. An explanation of the PPH is provided by the market microstructure literature. This is because liquidity changes in a significant manner as a result of the index revision news for both additions and deletions. The adjustment in liquidity causes trading volume and stock prices to reverse back to their original level before the index composition took place. Furthermore, our results remain intact after controlling for the impact of stock prices, trading volume, volatility of returns and free float shareholding percentage.

The liquidity effects in the index revisions of the KLCI could result in changes in firm value. This is because it may change the cost of borrowing after the changes in liquidity resulting from index additions and deletions. Extensions that focus on valuation of KLCI firms after the index revisions have taken place are promising avenues for future research. 
It would also be interesting to repeat the econometric analysis in our study at some point in the future. This is because our dataset is relatively small, with only 15 additions and 13 deletions to date for the KLCI. The small number of observations may cause jumps in the data that can produce volatile results. A larger dataset over a longer time period would establish more sound empirical findings. 


\section{References}

Amihud, Y., 2002. Illiquidity and Stock Returns: Cross-Sectional and Time-Series Effects. Journal of Financial Markets 5, 31-56.

Bhanot, K., Kadapakkam, P., 2006. Anatomy of a government intervention in index stocks: Price pressure or information effects? Journal of Business 79, 963-986.

Bechmann, K., 2004. Price and Volume Effects Associated with Changes in the Danish BlueChip Index: the KFX Index. Multinational Finance Journal 8, 3-34.

Beneish, M., Gardner, J., 1995. Information Costs and Liquidity Effects from Changes in the Dow Jones Industrial Average List. Journal of Financial and Quantitative Analysis 30, 135157.

Bildik, R., Gülay, G., 2008. The Effect of Changes in Index Composition on Stock Prices and Volume: Evidence from the Istambul Stock Exchange. International Review of Financial Analysis 17, 178-197.

Boehmer, E., Musumeci, J., Poulsen, A., 1991. Event-Study Methodology under Conditions of Event-Induced Variance. Journal of Financial Economics 30, 253-272.

Chen, H., Noronha, G., Singal, V., 2004. The Price Response to S\&P 500 Index Additions and Deletions: Evidence of Asymmetry and New Explanation. Journal of Finance 59, 1901-1930.

Dhillon, U., Johnson, H., 1991. Changes in the Standard and Poor's 500 List. Journal of Business 64, 75-85.

Elliott, W., Warr, R., 2003. Price Pressure on the NYSE and Nasdaq: Evidence from S\&P 500 Index Changes. Financial Management 32, 85-99.

Elliott, W., Warr, R., 2006. What Drives the S\&P Inclusion Effect? An Analytical Survey. Financial Management 35, 85-99.

Fama, E., 1970. Capital Markets: A Review of Theory and Empirical Work. Journal of Finance $25,383-417$.

Florackis, C., Gregoriou, A., Kostakis, A., 2011. Trading Frequency and Asset Pricing on the London Stock Exchange: Evidence from a New Price Impact Ratio. Journal of Banking and Finance 35, 3335-3350.

Gregoriou, A., 2011. The Liquidity Effects of Revisions to the CAC40 Stock Index. Applied Financial Economics 21, 333-34.

Gregoriou, A., Nguyen, N., 2010. Stock Liquidity and Investment Opportunities: New Evidence from FTSE Index Deletions. Journal of International Financial Markets, Institutions \& Money 20, 267-274. 
Hanaeda, H., Serita, T., 2003. Price and Volume Effects Associated with a Change in the Nikkei 225 Index List: New Evidence from the Big Change on April 2000. International Finance Review 4, 199-225.

Harris, L., Gurel, E., 1986. Price and Volume Effects Associated with Changes in the S\&P 500 list: New Evidence for the Existence of Price Pressures. Journal of Finance 41, 815-829.

Hegde, S., and McDermott, J., 2003. The Liquidity Effect of Revisions to the S\&P 500 Index: an Empirical Analysis. Journal of Financial Markets 6, 413-459.

Jain, P. (1987). The Effect on Stock Price of inclusion in or Exclusion from the S\&P 500. Financial Analysts Journal 43, 58-65.

Kim, O. and R. E. Verrecchia, 1994. Market liquidity and volume around earnings announcements. Journal of Accounting and Economics 17, 41-67.

Liu, S., 2000. Changes in the Nikkei 500: New Evidence for Downward Sloping Demand Curves for Stocks. International Review of Finance 1, 245-267.

Liu, S., 2011. The Price Effects of Index Additions: A New Explanation. Journal of Economics and Business 63, 152-165.

Lynch, A., Mendenhall, R., 1997. New Evidence on Stock Price Effects Associated with Changes in the S\&P 500 Index. Journal of Business 70, 351-383.

Madhavan, A., 2003. The Russell Reconstitution Effect. Financial Analysts Journal 59, 51-64.

Shleifer, A., 1986. Do Demand Curves for Stocks Slope down? Journal of Finance 41, 579-590.

Scholes, M., 1972. The Market for Securities: Substitution Versus Price Pressure and the Effects of Information on Share Prices. Journal of Business 45, 179-211

Stoll, H., 1978. The Pricing of Security Dealer Services: An Empirical Study of Nasdaq Stocks. Journal of Finance 23, pp. 1153-1172.

Stoll, H., 2000. Friction. Journal of Finance 55, 1479-1514.

Tavakoli, M., McMillan, D., McKnight, P., 2012. Insider Trading and Stock Prices. International Review of Economics and Finance 22, 254-266.

Vespro, C., 2006. Stock Price and Volume Effects Associated with Compositional Changes in European Stock Indices. European Financial Management 12, 103-127.

Yun, J., Kim, T., 2010. The Effect of changes in Index Constitution: Evidence from the Korean Stock Market. International Review of Financial Analysis 19, 258-269.

Woolridge, R., Ghosh, C., 1986. Institutional trading and security prices: The case of changes in the composition of the S\&P 500 index. Journal of Financial Research 9, 13-24. 


\section{Table 1}

This table describes and contrast the various theories related with stock prices and volume effects associated with changes in the composition of stock indices. In the first row one are the acronyms for the "Price Pressure Hypothesis" (PPH), the "Imperfect Substitutes Hypothesis" (ISH), the "Information hypothesis" (IH), and the "Information Cost and Liquidity Hypothesis" (ICLH); in the second row are brief definition of each hypothesis and related assumption(s); in the third row are some relevant articles which provide empirical evidence regarding each of the hypothesis.

\begin{tabular}{|c|c|c|c|}
\hline PPH & ISH & IH & ICLH \\
\hline $\begin{array}{l}\text { Assumes that the long-term demand is } \\
\text { perfectly elastic at full-information price -it } \\
\text { holds if stock prices reverse to their ex-ante } \\
\text { level after the index change, and recognizes } \\
\text { that immediate information about non- } \\
\text { information-motivated demand shifts may } \\
\text { be costly and, consequently, the short-term } \\
\text { demand curve may be less than perfectly } \\
\text { elastic. }\end{array}$ & $\begin{array}{l}\text { Assumes that securities are not close } \\
\text { substitutes for each other and so the long } \\
\text { term demand is less than perfectly elastic -in } \\
\text { equilibrium prices change when demand } \\
\text { curves shift to eliminate excess demand and } \\
\text { price reversals are not expected because the } \\
\text { new price reflects a new equilibrium } \\
\text { distribution of security holders. }\end{array}$ & $\begin{array}{l}\text { States that in efficient markets the positive } \\
\text { (negative) information about a stock should } \\
\text { increase (decrease) immediately its price } \\
\text { and the information effect should be } \\
\text { permanent -stocks prices should correctly } \\
\text { reflect the information content of the } \\
\text { indices additions and deletions and reach a } \\
\text { new equilibrium level upon the AD. }\end{array}$ & $\begin{array}{l}\text { Asserts that adding a stock to an index } \\
\text { leads to a higher market scrutiny and } \\
\text { information available, and that this } \\
\text { raises the attractiveness and the liquidity } \\
\text { of the stock and has a positive effect on } \\
\text { the price. }\end{array}$ \\
\hline Harris and Gurel (1986) & Scholes (1972) & Jain (1987) & Stoll (1978) \\
\hline Woolridge and Ghosh (1986) & Shleifer (1986) & Lynch and Mendenhall (1997) & Beneish and Gardner (1995) \\
\hline Dhillon and Johnson (1991) & Hanaeda and Serita (2003) & Denis et al. ( 2003) & Heflin and Shaw (2000) \\
\hline Liu ( 2000) & Bechmann (2004) & Liu (2011) & Hedge and McDermott (2003) \\
\hline Madhavan ( 2003) & Vespro (2006) & & Gregoriou (2011) \\
\hline Chen et al.(2004) & Bildik and Gülay ( 2008) & & \\
\hline \multicolumn{4}{|l|}{ Vespro (2006) } \\
\hline \multicolumn{4}{|l|}{ Bildik and Gülay ( 2008) } \\
\hline Yun and Kim (2010) & & & \\
\hline
\end{tabular}




\section{Table 2}

This table reports the KLCI changes between July 6, 2006 and September 15, 2012. The FTSE and BM review the KLCI semi-annually, at end of June and December. The main criteria for adding to or deleting from the index a constituent are the stock trading volume, the reliability of the stock price and the market capitalization. For instance, a stock is excluded when its market liquidity, measured by the stock's trading volume, falls below $0.04 \%$ of its issuance share, or if there is evidence that accurate and reliable prices are not available. The implementation of changes in the composition of the index takes place after the market closing on the third Friday of June or December of each year.

\begin{tabular}{ccc}
\hline KLCI & Additions & Deletions \\
\hline 2006 & 2 & 0 \\
2007 & 4 & 2 \\
2008 & 2 & 3 \\
2009 & 1 & 2 \\
2010 & 3 & 2 \\
2011 & 1 & 1 \\
2012 & 2 & 3 \\
\hline$\underline{\text { Total }}$ & $\underline{\mathbf{1 5}}$ & $\underline{\mathbf{3}}$ \\
\hline
\end{tabular}


Table 3

This table reports the "mean cumulative abnormal return" (MCAR) and the "volume ratio" (VR), as well as the respective t-statistic, for stocks added to the KLCI at the event-windows. The first column specifies the event-window, the second and the fourth columns reports the MCAR and the VR, respectively, and the third and fifth columns provides the t-statistic for the MCAR and the VR, respectively, for the eventwindows. Results are significant at $1 \%, 5 \%$ and $10 \%$ if identified by the superscripts ***, ** and *, respectively.

\begin{tabular}{lllll}
\hline Event-window (Additions) & MCAR & $\boldsymbol{t}$-statistic & Volume Ratio (VR) & $\boldsymbol{t}$-statistic \\
\hline AD-15, AD-1 & $3.624 \%$ & $2.283^{* *}$ & 2.119638872 & 1.445391935 \\
AD & $-0.102 \%$ & -0.0413 & 2.210734434 & 1.240471567 \\
AD, CD-1 & $-0.542 \%$ & -0.754 & 1.501520904 & 0.552855398 \\
CD & $0.063 \%$ & 0.0503 & 3.539289188 & $3.150931609 * * *$ \\
CD, CD+15 & $-1.578 \%$ & -0.917 & 1.869603518 & 0.79715725 \\
AD-15, CD-1 & $3.082 \%$ & $1.967 * *$ & 2.466967971 & $1.738665495 *$ \\
AD-15, CD+15 & $1.361 \%$ & 0.989 & 2.166533399 & 1.295451854 \\
AD,CD+15 & $-2.263 \%$ & -1.324 & 1.937170471 & 0.893167032 \\
\hline
\end{tabular}

Figure 1

Figure 1 shows the MCAR for the stocks added to the KLCI for the eventwidows/dates.

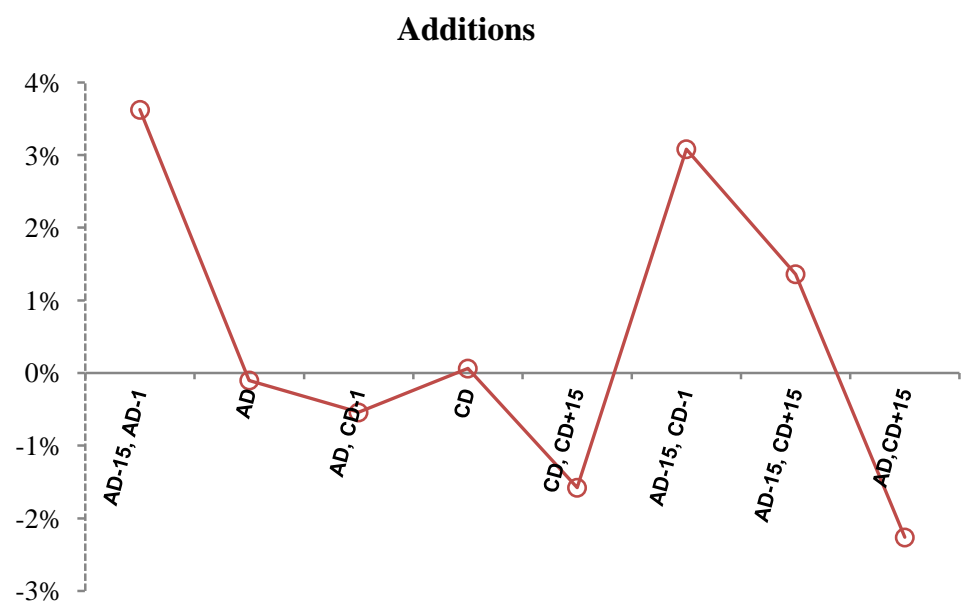

$\multimap$ MCAR (additions) 
Table 4

This table reports the "mean cumulative abnormal return" (MCAR) and the "volume ratio" (VR), as well as the respective t-statistic, for stocks deleted from the KLCI at the event-windows. The first column specifies the event-window, the second and the fourth columns reports the MCAR and the VR, respectively, and the third and fifth columns provides the t-statistic for the MCAR and the VR, respectively, for the event-windows. Results are significant at $1 \%, 5 \%$ and $10 \%$ if identified by the superscripts $* * *, * *$ and $*$, respectively.

\begin{tabular}{lllll}
\hline Event-window (Deletions) & MCAR & $\boldsymbol{t}$-statistic & Volume Ratio (VR) & $\boldsymbol{t}$-statistic \\
\hline AD-15, AD-1 & $-5.738 \%$ & $-2.567684819 * *$ & 1.247754288 & $-4.269514622^{* * *}$ \\
AD & $-0.493 \%$ & -0.346453949 & 1.448406355 & -1.073458842 \\
AD, CD-1 & $-1.561 \%$ & -1.400298946 & 1.623057844 & -0.693165614 \\
CD & $-1.002 \%$ & -0.32113723 & 1.439588545 & $-2.133042985 * *$ \\
CD, CD+15 & $7.342 \%$ & $3.48118939 * * *$ & 1.257233761 & $-3.899725612 * * *$ \\
AD-15, CD-1 & $-7.299 \%$ & $3.894621523 * * *$ & 1.545777059 & $-3.11647818 * *$ \\
AD-15, CD+15 & $0.043 \%$ & -0.715446249 & 1.45388126 & $-3.92907389 * * *$ \\
AD,CD+15 & $5.781 \%$ & $1.888962769 *$ & 1.407560291 & $-3.557902403 * * *$ \\
\hline
\end{tabular}

Figure 2

This figure shows the MCAR for the stocks deleted from the KLCI for the eventwindows/dates.

\section{Deletions}

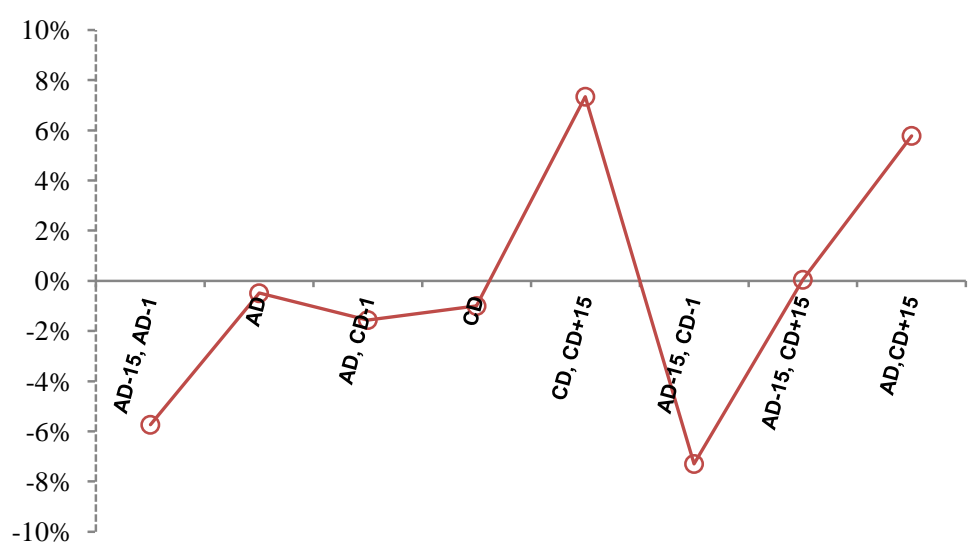

○-MCAR (deletions) 
Table 5

This table reports our results from the regression equation (5) for the stock additions. In the first column are the independent variables, where, "const." is the regression interception, $D_{-} K L C I_{t}$ is a dummy variable that takes the value of " 1 " for the period after the index change and " 0 " otherwise; $\log V \mathrm{ol}_{i, t}$, $\log \operatorname{Pr}_{i c e_{i, t}}$, and $\log \operatorname{StdDev}_{i, t}$ are, respectively, the natural logarithm of the stock $i$ 's average daily closing price, average daily trading volume in shares and daily return volatility, for the time period $t$; LogVolD_KLCI is the natural logarithm of the product of the stock added traded volume by the dummy variable $D_{-} K L C I_{t}$. In the second row from the second to the fifth columns are the regression independent variables, where LogSpread (quoted) is the natural logarithm of the stock bid-ask spread quoted, LogSpread (effective) is the natural logarithm of the stock bid-ask spread effective transacted, and RtoV and RtoTR are the return to trading and return to volume ratios defined for the equations (6) and (7), respectively. Results are significant at $1 \%, 5 \%$ and $10 \%$ if identified by the superscripts ***, ** and *, respectively.

\begin{tabular}{|c|c|c|c|c|}
\hline \multirow{2}{*}{$\begin{array}{l}\text { Additions } \\
\begin{array}{l}\text { Independent } \\
\text { Variables }\end{array}\end{array}$} & \multicolumn{4}{|c|}{ Dependant Variables } \\
\hline & $\begin{array}{l}\text { Log spread } \\
\text { (quoted) }\end{array}$ & $\begin{array}{l}\text { Log spread } \\
\text { (effective) }\end{array}$ & RtoV & RtoTR \\
\hline Const. & $\begin{array}{l}-3.868 \\
(-7.28) * * *\end{array}$ & $\begin{array}{l}-2.592 \\
(-1.32)\end{array}$ & $\begin{array}{l}0.000079 \\
(0.20)\end{array}$ & $\begin{array}{l}0.00737 \\
(0.08)\end{array}$ \\
\hline D_KLCI & $\begin{array}{l}0.729 \\
(5.60)^{* * *}\end{array}$ & $\begin{array}{l}1.542 \\
(3.23)^{* * *}\end{array}$ & $\begin{array}{l}0.003739 \\
(3.75)^{* * *}\end{array}$ & $\begin{array}{l}0.0899392 \\
(3.84)^{* * *}\end{array}$ \\
\hline $\log \mathrm{Vol}_{\mathrm{l}}$ & $\begin{array}{l}-0.026 \\
(-0.49)\end{array}$ & $\begin{array}{l}0.122 \\
(0.62)\end{array}$ & $\begin{array}{l}-0.001034 \\
(-2.47)^{* *}\end{array}$ & $\begin{array}{l}-0.0211 \\
(-2.14)^{* *}\end{array}$ \\
\hline $\log V_{\text {olD_LLCI }}$ & $\begin{array}{l}-0.245 \\
(-5.88)^{* * *}\end{array}$ & $\begin{array}{l}-0.414 \\
(-2.70)^{* *}\end{array}$ & $\begin{array}{l}-0.001212 \\
(-3.80)^{* * *}\end{array}$ & $\begin{array}{l}-0.291 \\
(-3.87)^{* * *}\end{array}$ \\
\hline $\log$ Price & $\begin{array}{l}0.693 \\
(0.098)\end{array}$ & $\begin{array}{l}-1.79 \\
(-0.69)\end{array}$ & $\begin{array}{l}0.0025 \\
(0.47)\end{array}$ & $\begin{array}{l}0.0622 \\
0.49)\end{array}$ \\
\hline $\operatorname{logStdDev}$ & $\begin{array}{l}-3.129 \\
(-0.91)\end{array}$ & $\begin{array}{l}-14.06 \\
(-1.11)\end{array}$ & $\begin{array}{l}0.00244 \\
(0.93)\end{array}$ & $\begin{array}{l}0.575 \\
(0.93)\end{array}$ \\
\hline$R^{2}$ & 0.6193 & 0.6378 & 0.6604 & 0.6402 \\
\hline
\end{tabular}


Table 6

This table reports our results from the regression equation (5) for the stock deletions. In the first column are the independent variables, where, "const." is the regression interception, $D_{-} K L C I_{t}$ is a dummy variable that takes the value of " 1 " for the period after the index change and " 0 " otherwise; $\log V \mathrm{ol}_{i, t}$, $\log \operatorname{Pr}_{i c e_{i, t}}$, and $\log \operatorname{StdDev}_{i, t}$ are, respectively, the natural logarithm of the stock $i$ 's average daily closing price, average daily trading volume in shares and the daily return volatility, for the time period $t$; LogVolD_KLCI is the natural logarithm of the product of the stock added traded volume by the dummy variable $D_{-} K L C I_{t}$. In the second row from the second to the fifth columns are the regression independent variables, where LogSpread (quoted) is the natural logarithm of the stock bid-ask spread quoted, LogSpread (effective) is the natural logarithm of the stock bid-ask spread effective transacted, and RtoTR and RtoV are the return to trading and return to volume ratios defined for the equations (7) and (6), respectively. Results are significant at $1 \%, 5 \%$ and $10 \%$ if identified by the superscripts ***, ** and *, respectively.

\begin{tabular}{l|llll}
\hline \multirow{2}{*}{ Deletions } & \multicolumn{4}{|c}{ Dependant Variables } \\
\hline $\begin{array}{l}\text { Independent } \\
\text { Variables }\end{array}$ & $\begin{array}{l}\text { log spread } \\
\text { (Quoted) }\end{array}$ & $\begin{array}{l}\text { log spread } \\
\text { (Effective) }\end{array}$ & RtoV & RtoTR \\
\hline Const. & -4.875 & -5.49 & -0.0000396 & -0.01883 \\
& $(10.87)^{* * *}$ & $(-4.22)^{* * *}$ & $(-2.28)^{* *}$ & $(-3.42)^{* * *}$ \\
D_KLCI & 0.5963 & -0.311 & 0.000463 & 0.011867 \\
& $(3.53)^{* * *}$ & $(-0.64)$ & $(7.08)^{* * *}$ & $(5.73)^{* * *}$ \\
$\log$ Vol & -0.0746 & -0.3288 & 0.00000082 & 0.003808 \\
& $(1.17)$ & $(-0.18)$ & $(3.56)^{* * *}$ & $(4.86)^{* *}$ \\
$\log$ VolD_KLCI & -0.1792 & -0.0784 & -0.0000145 & -0.0037 \\
& $(-3.23)^{* * *}$ & $(0.49)$ & $(-6.74)^{* * *}$ & $(-5.49)^{* * *}$ \\
$\log$ Price & 1.625 & 3.212 & 0.0000282 & 0.0152 \\
& $(2.15)^{* *}$ & $(1.48)$ & $(0.97)$ & $(1.63)$ \\
$\operatorname{logStdDev}$ & -2.77 & -7.091 & -0.0002677 & -0.1225 \\
& $(-0.70)$ & $(-0.62)$ & $(-1.73)$ & $(-2.51)^{* *}$ \\
\hline $\boldsymbol{R}^{\mathbf{2}}$ & 0.8267 & 0.720 & 0.5857 & 0.0877 \\
\hline
\end{tabular}




\section{Table 7}

This table reports, for the stock additions to the KLCI, the paired two sample means for the free float percentage of the "Government Held Shareholding" (NOSHGV), "Employee Held Shareholdings" (NOSHEM), sum of the "Government Held Shareholding" and the "Employee Held Shareholdings" (NOSHGV+NOSHEM), "Total Strategic Holding" (NOSHST), and the "Shares in Issue Available to Ordinary Investors" (NOSHFF), and respective t-statistic, for the event-windows. The first column specifies the event-windows, the second, fourth, sixth, eighth and tenth columns report the results for the NOSHGV, NOSHEM, NOSHGV+NOSHEM, NOSHT, and NOSHFF respectively, and the third, fifth, seventh, ninth and eleventh columns provide the respective t-statistic for each variable and event-window. Results are significant at $1 \%, 5 \%$ and $10 \%$ if identified by the superscripts $* * *, * *$ and $*$, respectively.

\begin{tabular}{|c|c|c|c|c|c|c|c|c|c|c|}
\hline $\begin{array}{l}\text { Event-window } \\
\text { (additions) } \\
\text { (1) }\end{array}$ & $\begin{array}{l}\text { NOSHGV (\%) } \\
\text { (2) }\end{array}$ & $\begin{array}{l}t \text {-stat } \\
\text { (3) }\end{array}$ & $\begin{array}{l}\text { NOSHEM (\%) } \\
\text { (4) }\end{array}$ & $\begin{array}{l}t \text {-stat } \\
(5)\end{array}$ & $\begin{array}{l}\text { NOSHGV } \\
\text { +NOSHEM (\%) } \\
\text { (6) }\end{array}$ & $\begin{array}{l}\text { t-stat } \\
\text { (7) }\end{array}$ & $\begin{array}{l}\text { NOSHST (\%) } \\
\text { (8) }\end{array}$ & $\begin{array}{l}\text { t-stat } \\
\text { (9) }\end{array}$ & $\begin{array}{l}\text { NOSHFF (\%) } \\
(10)\end{array}$ & $\begin{array}{l}\text { t-stat } \\
(11)\end{array}$ \\
\hline $\begin{array}{l}\text { AD-120,AD-1 } \\
\text { to }\end{array}$ & 2.076 & $9.296^{* * * *}$ & 1.0766 & $-3.9145 * * *$ & 3.153 & $7.451^{* * * *}$ & 31.700 & $2.1345 * *$ & 66.79 & $-10.44 * * *$ \\
\hline $\mathrm{CD}, \mathrm{CD}+120$ & 1.597 & & 1.133 & & 2.730 & & 31.317 & & 68.68 & \\
\hline $\begin{array}{l}\mathrm{AD}-30, \mathrm{AD}-1 \\
\text { to }\end{array}$ & 2.244 & $12.040 * * *$ & 1.133 & na & 3.378 & $12.04 * * *$ & 32.437 & $7.232 * * *$ & 67.56 & $-7.23 * * *$ \\
\hline $\mathrm{CD}, \mathrm{CD}+30$ & 1.8 & & 1.133 & & 2.933 & & 32.080 & & 67.92 & \\
\hline $\begin{array}{l}\mathrm{AD}-15, \mathrm{AD}-1 \\
\text { to }\end{array}$ & 2.155 & $5.291 * * *$ & 1.133 & na & 3.288 & $5.291 * * *$ & 32.333 & $3.150 * * *$ & 67.66 & $-3.15^{* * * *}$ \\
\hline $\mathrm{CD}, \mathrm{CD}+15$ & 1.8 & & 1.133 & & 2.933 & & 32.026 & & 67.97 & \\
\hline $\begin{array}{l}\mathrm{AD}-7, \mathrm{AD}-1 \\
\text { to }\end{array}$ & 1.952 & 1.549 & 1.133 & na & 3.086 & 1.5491 & 32.1047 & 1.5491 & 67.89 & -1.54 \\
\hline $\mathrm{CD}, \mathrm{CD}+7$ & 1.8 & & 1.133 & & 2.933 & & 31.933 & & 68.06 & \\
\hline
\end{tabular}




\section{Table 8}

This table reports our results for the regression equation (8) for the stock additions. In the first column are the independent variables, where, "const." is the regression interception, $D_{-} K L C I_{t}$ is a dummy variable that takes the value of " 1 " for the period after the index change and " 0 " otherwise; $\log V_{0}{ }_{i, t}$, $\log \operatorname{Pr}_{i c e_{i, t}}$, and $\log \operatorname{StdDev}_{i, t}$ are, respectively, the natural logarithm of the stock $i$ 's average daily closing price, average daily trading volume in shares and daily return volatility, for the time period $t$; LogVolD_KLCI is the natural logarithm of the product of the stock added traded volume by the dummy variable $D_{-} K L C I_{t}$; NOSHGVD_ KLCI, NOSHEMD_ KLCI, NOSHSTD_ KLCI and NOSHFFD_ KLCI are, the product of, respectively, the percentage of the "government held share", "employee held share", "strategic held share" and "publicly available shares" by the dummy variable $D_{-} K L C I_{t}$. In the second row, from the second to the fifth columns, are the regression dependent variables, where LogSpread (quoted) is the natural logarithm of the stock bid-ask spread quoted, LogSpread (effective) is the natural logarithm of the stock bid-ask spread effective transacted, and RtoTR and RtoV are the return to trading and return to volume ratios defined for the equations (7) and (6), respectively. Results are significant at $1 \%, 5 \%$ and $10 \%$ if identified by the superscripts $* * *, * *$ and $*$, respectively.

\begin{tabular}{|c|c|c|c|c|}
\hline Additions & \multicolumn{4}{|c|}{ Dependant Variables } \\
\hline $\begin{array}{l}\text { Independent } \\
\text { Variables }\end{array}$ & $\begin{array}{l}\text { log spread } \\
\text { (quoted) }\end{array}$ & $\begin{array}{l}\text { log spread } \\
\text { (effective) }\end{array}$ & RtoV & RtoTR \\
\hline Const. & $\begin{array}{l}-1.654 \\
(-7.12)^{* * *}\end{array}$ & $\begin{array}{l}-1.023 \\
(-1.20)\end{array}$ & $\begin{array}{l}0.0000708 \\
(0.17)\end{array}$ & $\begin{array}{l}0.0449 \\
(0.05)\end{array}$ \\
\hline $\log V_{o l}$ & $\begin{array}{l}-0.016 \\
(-0.70)\end{array}$ & $\begin{array}{l}0.027 \\
(0.31)\end{array}$ & $\begin{array}{l}-0.001044 \\
(-2.45)^{* *}\end{array}$ & $\begin{array}{l}-0.02127 \\
(-3.46)^{* * *}\end{array}$ \\
\hline $\log V_{\text {olD_KLCI }}$ & $\begin{array}{l}-0.0959 \\
(-4.58)^{* * *}\end{array}$ & $\begin{array}{l}-0.134 \\
(-1.75)^{*}\end{array}$ & $\begin{array}{l}-0.001246 \\
(-3.37)^{* * *}\end{array}$ & $\begin{array}{l}-0.0301 \\
(-4.00)^{* * *}\end{array}$ \\
\hline $\log$ Price & $\begin{array}{l}0.302 \\
(0.98)\end{array}$ & $\begin{array}{l}-0.751 \\
(-0.66)\end{array}$ & $\begin{array}{l}0.0025 \\
(0.47)\end{array}$ & $\begin{array}{l}0.0622 \\
(0.49)\end{array}$ \\
\hline $\log$ StdDev & $\begin{array}{l}-2.007 \\
(--1.01)\end{array}$ & $\begin{array}{l}-8.094 \\
(-1.18)\end{array}$ & $\begin{array}{l}0.00315 \\
(0.90)\end{array}$ & $\begin{array}{l}0.758 \\
(0.92)\end{array}$ \\
\hline NOSHGVD_KLCI & $\begin{array}{l}-0.0062 \\
(-1.04)\end{array}$ & $\begin{array}{c}-0.0176 \\
(-0.80)\end{array}$ & $\begin{array}{l}0.000000482 \\
(0.45)\end{array}$ & $\begin{array}{l}0.012 \\
(0.51)\end{array}$ \\
\hline NOSHEMD_KLCI & $\begin{array}{l}0.0057 \\
(1.02)\end{array}$ & $\begin{array}{l}0.0331 \\
(1.61)\end{array}$ & $\begin{array}{l}0.00000168 \\
(0.17)\end{array}$ & $\begin{array}{l}0.002 \\
(0.13)\end{array}$ \\
\hline NOSHSTD_KLCI & $\begin{array}{l}0.00311 \\
(4.02)^{* * *}\end{array}$ & $\begin{array}{l}0.0057 \\
(2.01)^{* *}\end{array}$ & $\begin{array}{l}0.00000317 \\
(2.72)^{* *}\end{array}$ & $\begin{array}{l}0.00893 \\
(2.78)^{* *}\end{array}$ \\
\hline NOSHFFD_KLCI & $\begin{array}{l}0.0027 \\
(4.15)^{* * *}\end{array}$ & $\begin{array}{l}0.0463 \\
(1.93)^{*}\end{array}$ & $\begin{array}{l}0.00000368 \\
(3.17)^{* * *}\end{array}$ & $\begin{array}{l}0.00896 \\
(3.28)^{* * *}\end{array}$ \\
\hline$R^{2}$ & 0.5746 & 0.6326 & 0.6787 & 0.6574 \\
\hline
\end{tabular}




\section{Table 9}

This table reports, for the stock deletions from the KLCI, the paired two sample means for free float percentage of the "Government Held Shareholding" (NOSHGV), "Employee Held Shareholdings" (NOSHEM), sum of the NOSHGV and the NOSHEM (NOSHGV+NOSHEM) and "Total Strategic Holding" (NOSHST), and the "Shares in Issue Available to Ordinary Investors" (NOSHFF), and respective t-statistic, for the event-windows. The first column specifies the event-window, the second, fourth, sixth, eighth and tenth columns reports the coefficients for the NOSHGV, NOSHEM, NOSHGV+NOSHEM, NOSHT and NOSHFF variables, respectively, and the third, fifth, seventh, ninth and eleventh columns provides the t-statistic for each variable and event-window. Results are significant at $1 \%$, $5 \%$ and $10 \%$ if identified by the superscripts $* * *, * *$ and $*$, respectively.

\begin{tabular}{|c|c|c|c|c|c|c|c|c|c|c|}
\hline $\begin{array}{l}\begin{array}{l}\text { Event-window } \\
\text { (deletions) }\end{array} \\
(1)\end{array}$ & $\begin{array}{l}\text { NOSHGV (\%) } \\
\text { (2) }\end{array}$ & $\begin{array}{l}t \text {-stat } \\
\text { (3) }\end{array}$ & $\begin{array}{l}\text { NOSHEM (\%) } \\
\text { (4) }\end{array}$ & $\begin{array}{l}t \text {-stat } \\
(5)\end{array}$ & $\begin{array}{l}\text { NOSHGV } \\
\text { +NOSHEM (\%) } \\
\text { (6) }\end{array}$ & $\begin{array}{l}\text { t-stat } \\
\text { (7) }\end{array}$ & $\begin{array}{l}\text { NOSHST (\%) } \\
\text { (8) }\end{array}$ & $\begin{array}{l}\text { t-stat } \\
\text { (9) }\end{array}$ & $\begin{array}{l}\text { NOSHFF (\%) } \\
(10)\end{array}$ & $\begin{array}{l}\text { t-stat } \\
\text { (11) }\end{array}$ \\
\hline $\begin{array}{l}\text { AD-120,AD-1 } \\
\text { to }\end{array}$ & 3.562 & $-71.1 * * *$ & 1.037 & $-10.7^{* * * *}$ & 4.600 & $-53.5 * * *$ & 32.516 & $-48.1^{* * * *}$ & 60.54 & $48.1^{\text {**** }}$ \\
\hline $\mathrm{CD}, \mathrm{CD}+120$ & 7.410 & & 2.020 & & 9.431 & & 49.508 & & 50.94 & \\
\hline $\begin{array}{l}\mathrm{AD}-30, \mathrm{AD}-1 \\
\text { to }\end{array}$ & 3.664 & $-20.3 * * *$ & 2.302 & 1 & 5.966 & $-18.1^{* * *}$ & 37.351 & $-18.7 * * *$ & 62.64 & $18.7^{* * * *}$ \\
\hline $\mathrm{CD}, \mathrm{CD}+30$ & 7.005 & & 2.230 & & 9.235 & & 49.441 & & 50.55 & \\
\hline $\begin{array}{l}\mathrm{AD}-15, \mathrm{AD}-1 \\
\text { to }\end{array}$ & 4.097 & $-10.9 * * *$ & 2.482 & $3.5^{* * *}$ & 6.579 & $-11.6^{* * *}$ & 39.451 & $-10.2^{* * *}$ & 60.54 & $10.17^{* * * *}$ \\
\hline $\mathrm{CD}, \mathrm{CD}+15$ & 7.076 & & 2.230 & & 9.307 & & 49.051 & & 50.94 & \\
\hline $\begin{array}{l}\mathrm{AD}-7, \mathrm{AD}-1 \\
\text { to }\end{array}$ & 4.901 & $-6.0^{* * *}$ & 2.230 & NA & 7.131 & $-5.9^{* * * *}$ & 42.780 & $-4.22 * * *$ & 57.21 & $4.21^{* * *}$ \\
\hline $\mathrm{CD}, \mathrm{CD}+7$ & 7.076 & & 2.230 & & 9.307 & & 48.384 & & 51.62 & \\
\hline
\end{tabular}




\section{Table 10}

This table reports our results for the regression equation (8) for the stock deletions. In the first column are the independent variables, where, "const." is the regression interception, $D_{-} K L C I_{t}$ is a dummy variable that takes the value of " 1 " for the period after the index change and " 0 " otherwise; $\log \operatorname{Vol}_{i, t}, \log \operatorname{Price}_{i, t}$, and $\log \operatorname{StdDev}_{i, t}$ are, respectively, the natural logarithm of the stock $i$ 's average daily closing price, average daily trading volume in shares and the daily return volatility, for the time period $t$; LogVolD_KLCI is the natural logarithm of the product of the stock added traded volume by the dummy variable $D_{-} K L C I_{t}$; NOSHGVD_ KLCI, NOSHEMD_ KLCI , NOSHSTD_ KLCI and NOSHFFD_ KLCI are the product of, respectively, the percentage of government held share, employee held shareholdings, strategic held shares and publicly available shares by the dummy variable $D_{-} K L C I_{t}$. In the second row, from the second to the fifth columns, are the regression independent variables, where LogSpread (quoted) is the natural logarithm of the stock bid-ask spread quoted, LogSpread (effective) is the natural logarithm of the stock bid-ask spread effective transacted, and RtoTR and RtoV are the return to trading and the return to volume ratios defined for the equations (6) and (7), respectively. Results are significant at 1\%,5\% and 10\% if identified by the superscripts $* * *, * *$ and $*$, respectively.

\begin{tabular}{|c|c|c|c|c|}
\hline \multirow{2}{*}{$\begin{array}{l}\underline{\text { Deletions }} \\
\begin{array}{l}\text { Independent } \\
\text { Variables }\end{array}\end{array}$} & \multicolumn{4}{|c|}{ Dependant Variables } \\
\hline & $\begin{array}{l}\text { log spread } \\
\text { (quoted) }\end{array}$ & $\begin{array}{l}\text { log spread } \\
\text { (effective) }\end{array}$ & RtoV & RtoTR \\
\hline Const. & $\begin{array}{l}-2.193 \\
(11.07)^{* * *}\end{array}$ & $\begin{array}{l}-2.274 \\
(-3.92)^{* * * *}\end{array}$ & $\begin{array}{l}0.0000391 \\
(-2.19)^{* *}\end{array}$ & $\begin{array}{l}0.03674 \\
(4.59)^{* * * *}\end{array}$ \\
\hline $\log V_{o l}$ & $\begin{array}{l}0.0513 \\
(1.82)\end{array}$ & $\begin{array}{l}0.0264 \\
(-0.03)\end{array}$ & $\begin{array}{l}-0.00000838 \\
(-3.31)^{* * *}\end{array}$ & $\begin{array}{l}-0.00338 \\
(-4.49) * * *\end{array}$ \\
\hline $\log \mathrm{VolD}_{-}$KLCI & $\begin{array}{l}-0.0107 \\
(-4.05) * * *\end{array}$ & $\begin{array}{l}-0.0102 \\
(-0.13)\end{array}$ & $\begin{array}{l}-0.000137 \\
(-5.73) * * *\end{array}$ & $\begin{array}{l}-0.00375 \\
(-5.50) * * *\end{array}$ \\
\hline $\log$ Price & $\begin{array}{l}0.781 \\
(2.32)^{* *}\end{array}$ & $\begin{array}{l}1.12 \\
(1.15)\end{array}$ & $\begin{array}{l}0.0000282 \\
(0.93)\end{array}$ & $\begin{array}{l}0.0171 \\
(1.79)^{*}\end{array}$ \\
\hline $\log \operatorname{StdDev}$ & $\begin{array}{l}-2.805 \\
(1.833)\end{array}$ & $\begin{array}{l}-2.789 \\
(-0.52)\end{array}$ & $\begin{array}{l}0.000217 \\
(-1.32)\end{array}$ & $\begin{array}{l}-0.122 \\
(-2.34) * * *\end{array}$ \\
\hline NOSHGVD_KLCI & $\begin{array}{l}0.010 \\
(3.74)^{* * *}\end{array}$ & $\begin{array}{r}0.0033 \\
(0.42)\end{array}$ & $\begin{array}{l}-0.000000255 \\
(-1.03)\end{array}$ & $\begin{array}{l}0.0000333 \\
(-0.42)\end{array}$ \\
\hline NOSHEMD_KLCI & $\begin{array}{l}0.0014 \\
(0.46)\end{array}$ & $\begin{array}{l}0.0057 \\
(0.61)\end{array}$ & $\begin{array}{l}0.000000249 \\
(-0.89)\end{array}$ & $\begin{array}{l}0.0000584 \\
(-0.63)\end{array}$ \\
\hline NOSHSTD_KLCI & $\begin{array}{l}0.0021 \\
(2.901)^{* * *}\end{array}$ & $\begin{array}{l}-0.0117 \\
(-0.80)\end{array}$ & $\begin{array}{l}0.000000477 \\
(7.17)^{* * *}\end{array}$ & $\begin{array}{l}0.0001218 \\
(5.79)^{* * *}\end{array}$ \\
\hline NOSHFFD_KLCI & $\begin{array}{l}0.0036 \\
(3.96)^{* * *}\end{array}$ & $\begin{array}{l}0.000682 \\
(0.26)\end{array}$ & $\begin{array}{l}0.000000438 \\
(7.17)^{* * *}\end{array}$ & $\begin{array}{l}0.000103 \\
(3.94)^{* * *}\end{array}$ \\
\hline$R^{2}$ & 0.7966 & 0.7525 & 0.6565 & 0.0830 \\
\hline
\end{tabular}

